\title{
Ânimo persecutório do magistrado: a quebra do dever de imparcialidade e sucessivas decisões contrárias ao direito à prova defensiva
}

Persecutory of the judge: breach of the duty of impartiality and
successive decisions contrary to the right to defensive evidence

\section{Fábio Agne Fayet ${ }^{1}$}

Faculdade da Serra Gaúcha - Caxias do Sul/RS

fabio@fayet.adv.br

http://lattes.cnpq.br/1361242497259188

D. http://orcid.org/0000-0002-3673-4538

\begin{abstract}
Roberta Eggert Poll ${ }^{2}$
Pontifícia Universidade Católica do Rio Grande do Sul - Porto Alegre/RS

roberta@fayet.adv.br

http://lattes.cnpq.br/5678667511758396

http://orcid.org/0000-0002-0667-2962
\end{abstract}

REsUMo: O tema do presente artigo é o ânimo persecutório do magistrado em desfavor do acusado. $O$ objeto de análise do trabalho é a verificação da quebra do dever de imparcialidade do magistrado quando da análise dos autos, mediante a aplicação de sucessivos entendimentos

1 Doutor em Ciências Criminais pela Pontifícia Universidade Católica do Rio Grande do Sul - PUCRS (2017). Mestre em Ciências Criminais pela Pontifícia Universidade Católica do Rio Grande do Sul - PUCRS (2001). Especialista em Direito Penal Econômico e Europeu pelo Instituto de Direito Penal Econômico e Europeu Coimbra/Portugal (2004). Graduado pela Universidade do Vale do Rio dos Sinos - UNISINOS (1998). Professor de Direito Penal e Processo Penal da Faculdade da Serra Gaúcha. Advogado Criminalista.

2 Mestre em Ciências Criminais pela Pontifícia Universidade Católica do Rio Grande do Sul - PUCRS (2018). Pós-graduada em Direito Público pela Universidade Estácio de Sá. (2013). Bacharelada em Direito pela Universidade Estácio de Sá. (2010). Advogada Criminalista. 
contrários aos interesses do acusado. O objetivo de pesquisa é a verificação da existência ou não de um dever de imparcialidade do magistrado diante de decisões motivadas, proferidas no exercício independente da atividade jurisdicional e impugnáveis por recurso ou ação autônoma, com nítido caráter persecutório. O método de abordagem será o dedutivo, adotando-se como procedimento o bibliográfico. Destarte, em primeiro, propõe, o presente artigo, uma leitura sobre a imparcialidade e o protagonismo do magistrado de modo a indicar como a literatura contemporânea vem enxergando a postura do juiz frente ao acusado, para, depois, analisar-se a questão da quebra do dever de imparcialidade diante de sucessivas decisões que se traduzem em uma atuação persecutória do juiz.

Palavras-Chave: Imparcialidade; Julgador; Ânimo persecutório; Motivação; Direito à prova.

ABSTRACT: The theme of this article is the persecutory mood of the magistrate in disfavor of the accused. The object of analysis of the work is the verification of the breach of the duty of impartiality of the magistrate when analyzing the records, through the application of successive understandings contrary to the interests of the accused. The research hypothesis is the verification of the existence or not of a duty of impartiality of the magistrate before motivated decisions, given in the independent exercise of the jurisdictional activity and can be challenged by autonomous action or action, with clear persecutory character. The method of approach will be deductive, adopting as a bibliographical procedure. Firstly, this article proposes a reading on the impartiality and protagonism of the magistrate in order to indicate how contemporary literature has been seeing the judge's position vis-à-vis the accused, and then to analyze the issue of breach of the duty of impartiality before successive decisions that translate into a persecutory performance of the judge.

KEYwORDs: Impartiality; Judge; Persecutory mood; Motivation; Right to proof.

SUMÁRIO: Introdução; 1. Imparcialidade e protagonismo do magistrado: quando o dever de fundamentação assume ares persecutórios; 2. Crise identitária do magistrado: quando o ânimo persecutório atinge o dever de imparcialidade; Considerações Finais; Referências. 


\section{INTRODUÇÃO}

Calamandrei já nos norteava: "Imparcial deve ser o juiz, que está acima dos contendores; mas os advogados são feitos para serem parciais, não apenas porque a verdade é mais facilmente alcançada se escalada de dois lados, mas porque a parcialidade de um é o impulso que gera o contra-impulso do adversário, o estímulo que suscita a reação do contraditor e que, através de uma série de oscilações quase pendulares de um extremo a outro, permite ao juiz apreender, no ponto de equilíbrio, o justo". ${ }^{3}$

Juiz justo é juiz imparcial. ${ }^{4}$ Afinal de contas, a falibilidade é algo intrínseco à natureza humana e para que estas arestas sejam aparadas é preciso respeito irrestrito às garantias constitucionais que estabelecem os verdadeiros remédios contra as mazelas humanas dos magistrados.

A imparcialidade também se relaciona com a ideia de jurisdição, desenvolvida no século XVIII por meio da teoria da separação dos poderes de Montesquieu. ${ }^{5}$ Para o jurista francês não seria possível conceber uma atuação imparcial se o magistrado agisse fora da lei. Por isso, a doutrina vem enfatizando que "a jurisdição não existe se não for imparcial". ${ }^{6}$

Neste contexto urge a imperiosa necessidade de se analisar a existência de uma das violações mais graves ao sistema acusatório e às garantias constitucionais do acusado, qual seja o ânimo persecutório do magistrado em desfavor do réu. ${ }^{7}$

3 CALAMANDREI, Piero. Eles, os juízes, vistos por nós, os advogados. São Paulo: Martins Fontes, 2000, p. 126.

4 Conforme Aury Lopes Jr., a imparcialidade subjetiva diz respeito à "convicção pessoal do juiz concreto, que conhece de um determinado assunto e, desse modo, a sua falta de pré-juízos"; enquanto a imparcialidade objetiva considera "se tal juiz encontra-se em uma situação dotada de garantias bastantes para dissipar qualquer dúvida razoável acerca da sua imparcialidade" (LOPES JR, Aury. Direito processual penal. 10. ed. São Paulo: Saraiva, 2013, p. 522).

5 MONTESQUIEU, Charles de Secondat, Baron de. O espírito das leis. Tradução de Cristina Murachco. São Paulo: Martins Fontes, 1996, p. 19-26.

6 ZAFFARONI, Eugênio Raul. Poder Judiciário: Crises acertos e desacertos. Tradução: Juarez Tavares. São Paulo: Revista dos Tribunais, 1995. p. 86.

7 Denota-se que a garantia da imparcialidade vem sendo considerada pela doutrina contemporânea como a base e o elemento diferenciador da atividade judicante em relação ao demais poderes. Nesse sentido ver: POZZEBON, 
Por certo, o problema de pesquisa visa a responder a questão relativa à quebra do dever de imparcialidade por razões não declaradas pelo magistrado e supostamente diversas das subjacentes à real motivação de suas decisões, na medida em que o juiz que adota uma postura persecutória acaba por violar a garantia constitucional do julgamento isento e imparcial e, por razões lógicas, o sistema acusatório.

Efetivamente, o objetivo sobre o qual se trabalha é relativo à verificação da existência ou não de um dever de imparcialidade do magistrado diante de decisões motivadas, proferidas no exercício independente da atividade jurisdicional e impugnáveis por recurso ou ação autônoma, com nítido caráter persecutório. Assim, pretende-se verificar se: as decisões judiciais, em que se justifique a escolha de uma interpretação possível, são aptas, por si só, a gerar a suspeição do seu prolator e revisão pelas instâncias superiores quando o magistrado atuar de forma direcionada a prejudicar o acusado?

Isto porque, a jurisprudência tem apontado que não se pode considerar suspeito um magistrado por continuamente decidir de acordo com a tese desenvolvida pela acusação pública, pois se estaria atingindo, desta forma, o pleno exercício da atividade jurisdicional. Outrossim, a quebra do dever de imparcialidade não se confundiria com sucessivas decisões contrárias aos interesses do réu. ${ }^{8}$

Não obstante, analisando-se a fundo a questão relativa à garantia constitucional do julgamento isento e imparcial (CF, art. $5^{\circ}$, inciso LIII) verifica-se que o próprio Supremo Tribunal Federal já decidiu no sentido do reconhecimento da suspeição do magistrado quando esse estiver vinculado à matéria objeto da denúncia e à atividade investigatória. ${ }^{9}$ Desta forma, igual pensamento poderia ser adotado quando o magistrado atuasse em evidente ânimo persecutório, ultrapassando os limites da atividade jurisdicional, adotando uma postura de acusador público, gerenciando o processo de modo a decidir sempre tendo em vista a condenação do acusado.

Fabrício Dreyer de Ávila. A imparcialidade do juiz criminal enquanto ausência de causas de impedimento ou de suspeição. Direito e Justiça, Porto Alegre, ano 39, n.1, p. 116-220, jan./jun. 2013, p. 116.

8 Nesse sentido, veja o seguinte julgado paradigma: STF, RHC no 127.256/SP, relator Ministro Gilmar Mendes, DJe 10-03-2016.

9 STF, HC no 95.009/SP, relator Ministro Eros Grau, DJe de 19-12-2008. 
Para a análise do objeto de pesquisa aqui delimitado será utilizada a técnica de pesquisa bibliográfica e documental consistente em explicar o problema por meio das teorias publicadas em obras de um mesmo gênero, partindo do geral para o particular, permitindo a construção das conclusões. O método empregado será o dedutivo, consistente em utilizar o raciocínio lógico que faz uso da dedução para obter a conclusão.

Por estas razões, o presente artigo está estruturado de forma a permitir, em primeiro, uma leitura sobre a imparcialidade e o protagonismo do magistrado de modo a indicar como a literatura contemporânea vem enxergando a postura do juiz frente aos requerimentos do acusado, para, posteriormente, analisar-se a questão da quebra do dever de imparcialidade diante de sucessivas decisões que se traduzem em uma atuação persecutória do magistrado.

\section{IMPARCIALIDADE E PROTAGONISMO DO MAGISTRADO: QUANDO O DEVER DE FUNDAMENTAÇÃo ASSUME "ARES PERSECUTÓRIOS"}

Montesquieu, há tempos já nos recordava que "o juiz é a boca que pronuncia as palavras da lei... um ser inanimado". Pretendia o jurista francês isolar o magistrado das mazelas mundanas como se o julgador fosse uma espécie de médium, uma máquina que fala por meio de leis, que diz o que deve ser dito conforme está escrito. Seu contexto sociocultural, sua vivência, histórias e experiências passadas não deveriam influenciar no julgamento, ou seja, o magistrado tornava-se mero intérprete do que o legislador real expressava. A lei era tomada na sua literalidade, desta forma, o juiz não deveria ter nenhum protagonismo. ${ }^{10}$

Invariavelmente, esse modelo de justiça acabou por ingressar em profunda crise, pois o magistrado apesar de ignorar os fatos, não é neutro, na medida em que possui conotações políticas, ideológicas, religiosas, econômicas, e etc., que o fazem ser um juiz-no-mundo. ${ }^{11}$ Não

10 MONTESQUIEU, Charles de Secondat, Baron de. O espírito das leis. Tradução de Cristina Murachco. São Paulo: Martins Fontes, 1996, p. 151.

11 GIACOMOLLI, Nereu José; DUARTE, Liza Bastos. O mito da neutralidade na motivação das decisões judiciais: aspectos epistemológicos. Revista da Ajuris, Porto Alegre, ano 33, n. 102, p. 288-307, jun. 2006, p. 290. 
existe juiz neutro. Existe sim, juiz imparcial. ${ }^{12} \mathrm{~A}$ imparcialidade é um princípio supremo do processo, como ensina Goldschmdit, fundante da própria dialética processual. ${ }^{13}$ Para que um processo se desenvolva de maneira devida e justa é imperioso que se tenha um julgador imparcial.

Em verdade, a imparcialidade deve ser compreendida, consoante os ensinamentos de Fazzalari, como uma restrição aos poderes instrutórios do magistrado, mantendo-se este afastado da prática de atividades de investigação ou instrução processual, na medida em que tal tarefa incumbe somente as partes (acusador público e acusado), sob pena de configurar-se um processo penal inquisitório. ${ }^{14}$

Sem imparcialidade não há jurisdição. ${ }^{15}$ Por isso bastaria que a Constituição trouxesse no rol do artigo $5^{\circ}$ um inciso que dispusesse acerca da imparcialidade. Contudo, optou o legislador constitucional em assegurar outras condições de independência, a fim de vedar quaisquer práticas forenses que pudessem colocar em risco a imparcialidade do julgador (CF, art. 95, caput).$^{16}$ Tratam-se de garantias inerentes à autonomia da carreira

12 Á título de exemplificação veja-se que, a imparcialidade encontra, desde, 1950, o status de direito protegido pela Convenção Europeia de Direitos Humanos, à medida que o artigo $6^{\circ}$ trata do direito do acusado de ter um julgamento justo. Compare em: POZZEBON, Fabrício Dreyer de Ávila. A imparcialidade do juiz no processo penal brasileiro. Revista da Ajuris, Porto Alegre, ano 34, n. 108, p-116-120, dez. 2007, p. 171.

GOLDSCHMIDT, Werner. La imparcialidad como principio básico del proceso: la partialidad y la parcialidade. Madrid: Gráfica Clemares, 1950. p. 19-21.

14 FAZZALARI, Elio. Instituições de Direito Processual. Tradução de Eliane Nassif. 8. ed. Campinas: Imprenta, 2006, p. 119 e 135.

15 A importância da ideia de jurisdição, em substituição à tutela privada é justamente o pressuposto de que o estado-juiz é terceiro imparcial, a quem fora atribuída a incumbência de pacificar os conflitos sociais. O monopólio do estado-juiz sobre a jurisdição e a vedação à autotutela impõe que o magistrado atue de forma absolutamente imparcial. Sobre isso, ver: CABRAL, Antônio. Imparcialidade e impartialidade. Por uma teoria sobre repartição e incompatibilidade de funções nos processos civil e penal. Revista de Processo, São Paulo, ano 32, n. 149, p. 339-364, jul. 2007, p. 345-346.

16 BADARÓ, Gustavo Henrique Righi Ivahy. Direito a um julgamento por juiz imparcial: como assegurar a imparcialidade objetiva do juiz nos sistemas em que não há a função do juiz de garantias. In: BONATO, Gilson (Org.). Processo Penal, Constituição e Críticas - Estudos em homenagem ao Prof. Dr. Jacionto Nelson de Miranda Coutinho. Rio de Janeiro: Lumen Juris, 2011, p. 343. 
judiciária (vitaliciedade, inamovibilidade e irredutibilidade de subsídio), consideradas por Leone como indispensáveis ao exercício independente do juiz em suas funções, afastando a possibilidade de qualquer pressão externa, seja particular, seja por outro órgão do Estado. ${ }^{17}$

Pois bem, imparcialidade também não se confunde com protagonismo. Dizer o Direito não corresponde a "dizer o que se quer porque se pode". ${ }^{18}$ Os magistrados têm proeminência na interpretação das leis, mas isso não é o resultado de sua própria vontade e muito menos de suas ideologias. ${ }^{19} \mathrm{O}$ Direito que serve como base para que o juiz tome decisões é, por sua própria natureza, indeterminado. Como Larenz explica, a relação do texto legal com a atividade do intérprete é "duplamente variável". ${ }^{20}$ Isto porque a norma abstrata não pode prever todos os casos, mas um conjunto deles; e o intérprete ao selecionar um padrão para resolver um caso específico deverá inseri-lo dentro de seu próprio sistema de crenças, mas também dentro do Direito, a partir de efetiva fundamentação. ${ }^{21}$

A fundamentação das decisões judiciais destina-se, portanto, a reduzir a imprevisibilidade do magistrado e seu protagonismo, controlando o caos processual. ${ }^{22}$ A prática legal tem que desconstituir

17 LEONE, Giovanni. Come si svolge un processo penale. Torino: ERI, 1967. p. 116.

18 ARAMBURO RESTREPO, José Luís. El papel del juez: una aproximación teórica. Pensamiento Jurídico, Bogotá, ano 16, n. 27, p. 85-106, jan./abr. 2010, p. 88 (tradução livre).

19 Diversas pesquisas de opinião têm apontado a tendência político-criminal conservadora da Magistratura nacional, sobretudo quando se fala em juízos de primeira instância. A opção ideológica por correntes punitivistas demonstra que a influência do populismo punitivo não se restringe apenas à esfera Legislativa, exercendo grande ingerência sobre os operadores do direito. Sobre isso, ver: CARVALHO, Salo de. O papel dos atores no sistema penal na era do punitivismo. O exemplo privilegiado da aplicação da pena. Rio de Janeiro: Lumen Juris, 2010, p. 104.

20 LARENZ, Karl. Metodología de la Ciencia del Derecho. Barcelona: Ariel, 1994, p. 308-316 (tradução livre).

21 ARAMBURO RESTREPO, José Luís. El papel del juez: una aproximación teórica. Pensamiento Jurídico, Bogotá, ano 16, n. 27, p. 85-106, jan./abr. 2010, p. 88.

22 Essa forma de pensar é geralmente atribuída a Dworkin, mas antes dele, os estudiosos da metodologia da lei, como o próprio Savigny, enfrentaram essa tarefa. Compare em: LARENZ, Karl. Metodología de la Ciencia del Derecho. Barcelona: Ariel, 1994, p. 308-316. 
o dualismo tradicional entre conhecimento e criação de forma semelhante à prática artística: com efeito, tanto entre juristas como entre artistas a criação é uma atividade livre e autônoma, individual feita de pura inspiração e arbitrariedade, mas é também uma prática regulamentada e considerada válida, apenas por consenso, aceitação social e correlata fundamentação. ${ }^{23}$

Essa perspectiva corresponde a um conceito legal de motivação, como resumem Grinover, Fernandes e Gomes Filho: “A motivação surge como instrumento por meio do qual as partes e o meio social tomam conhecimento da atividade jurisdicional; as partes para, se for o caso, impugnarem os fundamentos da sentença, buscando seja reformada; a sociedade a fim de que possa formar opinião positiva ou negativa a respeito da qualidade dos serviços prestados pela justiça. (...) qualquer resolução contida no provimento jurisdicional exige suficientemente motivação do juiz, quer incida sobre questões de fato ou de direito, quer se refira a questões relacionadas com o direito de ação, com a validade do processo ou com o mérito da causa”. ${ }^{24}$

Como se sabe, todas as questões suscitadas e discutidas no processo, sejam preliminares ou de mérito, devem ser enfocadas na fundamentação do julgador, sob pena de insanável nulidade. O artigo 381, inciso III, do CPP assegura que a sentença conterá a indicação dos motivos de fato e de direito em que se fundar a decisão, preconizando que os magistrados têm o dever se explicitar o caminho trilhado para chegar à sua conclusão. Igualmente, a garantia de motivação dos atos judiciais também está consagrada no art. 93, inciso IX, da CRFB. Isto porque, a efetiva participação e controle das decisões judiciais através da fundamentação é requisito revelador do princípio do Estado Democrático de Direito. Segundo Barbosa Moreira, "o controle 'extraprocessual' deve ser exercitável, antes de mais nada, pelos jurisdicionados 'in genere', como tais. A sua viabilidade é condição essencial para que, no seio da comunidade, se

23 ARAMBURO RESTREPO, José Luís. El papel del juez: una aproximación teórica. Pensamiento Jurídico, Bogotá, ano 16, n. 27, p. 85-106, jan./abr. 2010, p. 89.

${ }^{24}$ GRINOVER, Ada Pellegrini; FERNANDES, Antônio Scarance; GOMES FILHO, Antônio Magalhães. As Nulidades do Processo Penal. 4. ed. São Paulo: Malheiros, 1995, p. 169. 
fortaleça a confiança na tutela jurisdicional - fator inestimável, no Estado de Direito, da coesão social e da solidez das instituições". ${ }^{25}$

Tamanha é a preocupação com essa questão que diversos diplomas internacionais mencionam a necessidade de preservação da cognição do magistrado no processo, para que nenhuma parte seja beneficiada em detrimento da outra, senão vejamos: a Declaração Universal dos Direitos Humanos (art. 10), a Declaração Americana dos Direitos Humanos (art. 26.2), a Convenção Americana de Direitos Humanos (art. 8.1), o Pacto Internacional dos Direitos Civis e Políticos (art.14.1) e a Convenção Europeia para Proteção dos Direitos Humanos e das Liberdades Fundamentais (art. 6.1). ${ }^{26}$

A sentença penal, mais do que qualquer outra decisão no sistema jurídico, deve guardar pertinência concreta com o caso sub judice. Exige-se, portanto, que a decisão apresente fundamentação adequada, qualidade esta que somente se fará presente caso a linha de raciocínio utilizada pelo julgador seja objetiva e vinculada ao fato em exame. ${ }^{27}$ Em outras palavras, a dogmática processual penal relaciona o dever de motivação das decisões com o controle democrático da atividade jurisdicional e, consequentemente, com o controle da parcialidade dos juízes. ${ }^{28}$

Não por outro motivo que o protagonismo judicial deve começar com a determinação do quadro fático, dentro do qual a decisão deve ser tomada. Para Duncan Kennedy, referenciado por Aramburo Restrepo, em sua decisão "o juiz deverá se opor a uma resistência discursiva à

25 MOREIRA, José Carlos Barbosa. A motivação das decisões judiciais como garantia inerente ao Estado de Direito. In: Temas de Direito Processual. São Paulo: Saraiva, 1988, p. 90.

26 Todos os diplomas foram referenciados por: RITER, Ruiz. Imparcialidade no processo penal: reflexões a partir da teoria da dissonância cognitiva. 2016. $196 \mathrm{f}$. Dissertação (Mestrado em Ciências Criminais) - Faculdade de Direito, Pontifícia Universidade Católica do Rio Grande do Sul, Porto Alegre, 2016, p. 56-57.

27 GIACOMOLLI, Nereu José. O devido processo penal. Abordagem conforme a Constituição Federal e o Pacto de São José da Costa Rica. Cases da Corte Interamericana, do Tribunal Europeu e do STF. Porto Alegre: Atlas. 2.ed., 2015, p. 212-216.

28 BATISTA, Bárbara Gomes Lupetti. Reflexões sobre o dever de fundamentação das decisões judiciais e a imparcialidade judicial: "o que falar quer dizer" e o que dizer não quer falar? Amazon's Research and Environmental Law, Ariquemes, ano 3, n. 3, p. 107-130, set. 2015, p. 112. 
sentença que ele deseja ditar, em nome dos obstáculos objetivos do direito". ${ }^{29}$ Contudo, nem sempre os magistrados percorrem o caminho correto, utilizando-se por vezes de um "método inverso": já decidem a demanda com o oferecimento da denúncia. O processo, assim, passa a ter ares inquisitoriais; o magistrado, por sua vez, passa a "perseguir a colheita da prova" de forma que toda decisão é tomada tendo em vista a condenação do acusado, o que acaba por violar, consequentemente, a garantia da imparcialidade e do julgamento justo. ${ }^{30}$

Quando esses acontecimentos aparecem, o magistrado assume um juízo positivo sobre a participação do acusado nos eventos criminosos, produzindo em seu âmago "pré-juízos sobre a culpabilidade que lhe impedirão de decidir, posteriormente, com total isenção e imparcialidade". ${ }^{31} \mathrm{~A}$ bem da verdade, o "juiz sabe que ele julga como quer”, como já assegurava Nalini, no que corrobora que: "É fácil encontrar argumentos contra ou a favor de qualquer das teses. Fundamental se torna a sua profunda honestidade intelectual, fomentada pela humildade intelectual, para que, no ato de julgar não prevaleçam as idiossincrasias, os preconceitos, o comodismo ou qualquer outro subjetivismo, sobre a missão de fazer justiça”. ${ }^{2}$

A ausência de consenso oficial sobre o conteúdo e as formas de interpretação da lei assegura aos juízes, ou melhor, deles exige que preencham esses espaços vazios como querem. Veja-se que "fazer o que

29 KENNEDY, Duncan. Libertad y restricción en la decisión judicial. Bogotá: Universidad de Los Andes, 1998 apud ARAMBURO RESTREPO, José Luís. El papel del juez: una aproximación teórica. Pensamiento Jurídico, Bogotá, ano 16, n. 27, p. 85-106, jan./abr. 2010, p. 98.

30 Sobre a metodologia do sistema inquisitório recomenda-se a leitura de: EYMERICH, Nicolau. Directorium Inquisitorum: Manual dos Inquisidores: Escrito por Nicolau Eymerich em 1376, revisto e ampliado por Francisco de La Peña em 1578. Rio de Janeiro: Rosa dos Ventos, Brasília: Fundação Universidade de Brasília, 1993.

31 BADARÓ, Gustavo Henrique Righi Ivahy. Direito a um julgamento por juiz imparcial: como assegurar a imparcialidade objetiva do juiz nos sistemas em que não há a função do juiz de garantias. In: BONATO, Gilson (Org.). Processo Penal, Constituição e Críticas - Estudos em homenagem ao Prof. Dr. Jacionto Nelson de Miranda Coutinho. Rio de Janeiro: Lumen Juris, 2011, p. 345.

32 NALINI, José Renator. Humildade do juiz. Disponível em: <http://portal.tjro. jus.br/documents/18/24335/A+HUMILDADE+DO+JUIZ.pdf>. Acesso em: 06 fev. 2018. 
se quer", como lembra Lupetti Batista: "não significa necessariamente uma estigmatização ou hostilização", mas sim "decidir segundo uma convicção pessoal sobre o que parece ser o mais justo diante de determinada situação". ${ }^{33} \mathrm{O}$ problema surge quando o julgamento passa a ser realizado de forma interessada ou comprometida com alguma das partes do processo, especialmente a acusação pública. ${ }^{34}$

Veja-se que, não é tarefa simples demonstrar diante do caso concreto a parcialidade do magistrado, na medida em que este tem ao seu lado a "íntima convicção motivada", podendo fundamentar suas decisões de acordo com os interesses do acusador público ou do acusado. Não obstante, é possível perceber "alguns sintomas" sempre que há violação da cláusula do dever de imparcialidade. Passamos a análise dessas particularidades no tópico seguinte.

\section{Crise identitária do magistrado: quando o ÂNIMO PERSECUTÓRIO ATINGE O DEVER DE IMPARCIALIDADE}

A viabilização da cláusula de imparcialidade liga-se à ideia de separação de funções, ou seja, o papel de acusar e julgar não pode recair sobre a mesma pessoa em vista da adoção de um sistema acusatório. ${ }^{35} \mathrm{Tal}$ concepção também é seguida por Cordón Moreno, que considera garantia

33 BATISTA, Bárbara Gomes Lupetti. Reflexões sobre o dever de fundamentação das decisões judiciais e a imparcialidade judicial: "o que falar quer dizer" e o que dizer não quer falar? Amazon's Research and Environmental Law, Ariquemes, ano 3, n. 3, p. 107-130, set. 2015, p. 114.

34 Afinal, como assegura Badaró: "Não há como se conceber a existência de um processo com a decisão nas mãos de um terceiro interessado em prejudicar ou beneficiar uma das partes. É ínsito ao processo um juiz imparcial sem o que deixará de haver processo." (BADARÓ, Gustavo Henrique Righi Ivahy. Direito processual penal. Tomo I. Rio de Janeiro: Elsevier, 2008. p. 6).

35 À título de caracterização apresenta-se o sistema acusatório sempre que houver: (a) separação das funções de acusar e julgar; b) acusação realizada por qualquer do povo (em alusão ao modelo clássico, hoje de titularidade do MP); c) impossibilidade de acusação de ofício; d) livre produção probatória; e) possibilidade de ampla defesa; f) debates (instrução) públicos e orais; g) juiz titular exclusivo do poder de decidir; e h) prevalência do interesse particular sobre o interesse social. Compare em: LOPES JR., Aury. Fundamentos do processo penal: introdução crítica. São Paulo: Saraiva, 2015. p. 155-157. 
básica da imparcialidade o desmembramento das funções acusatória e julgadora, pois somente o Ministério Público pode ser considerado "parte na relação jurídico-processual”, ficando responsável pela persecução penal. ${ }^{36}$ Ao juiz, em vista da garantia da imparcialidade, resta tão somente a condição de "terceiro desinteressado em relação as partes", um estranho alheio aos interesses processuais ${ }^{37}$ - no exato sentido da terzietá proposta pela literatura especializada italiana. ${ }^{38}$

O problema surge quando o magistrado adentra a função acusadora, ou seja, quando o juiz adota uma postura persecutória em desfavor do réu, utilizando-se da cláusula da íntima convicção como escudo protetor de suas decisões persecutórias.

Primeiramente, há que se ressaltar que "a dúvida acerca da parcialidade do julgador há de ser fundada em circunstâncias fáticas objetivas e em um determinado caso concreto". ${ }^{39}$ Dito de outra forma, à parte caberá demonstrar que a disposição psicológica e a conduta exteriorizada do julgador são sintomas de falta de imparcialidade. Isto porque meras suposições não são suficientes à instauração de uma exceção de suspeição. ${ }^{40}$

Por conseguinte, na perspectiva do que apresenta o sistema acusatório, partindo-se da concepção de um princípio dispositivo (que coloca a gestão da prova nas mãos das partes - acusador público e acusado), descabe falar em produção probatória pelo magistrado. ${ }^{41}$ No ponto,

36 CORDÓN MORENO, Faustino. Las garantias constitucionales del proceso penal. 2. ed. Navarra: Arazandi, SA, 2002, p. 129.

37 BADARÓ, Gustavo Henrique Righi Ivahy. Direito processual penal. Tomo I. Rio de Janeiro: Elsevier, 2008. p. 6.

38 Sobre a contribuição da doutrina italiana veja: FAZZALARI, Elio. Instituições de Direito Processual. Tradução de Eliane Nassif. 8. ed. Campinas: Imprenta, 2006.

39 GIACOMOLLI, Nereu José. O devido processo penal. Abordagem conforme a Constituição Federal e o Pacto de São José da Costa Rica. Cases da Corte Interamericana, do Tribunal Europeu e do STF. 2.ed. Porto Alegre: Atlas, 2015, p. 235.

40 RITER, Ruiz. Imparcialidade no processo penal: reflexões a partir da teoria da dissonância cognitiva. 2016. 196f. Dissertação (Mestrado em Ciências Criminais) - Faculdade de Direito, Pontifícia Universidade Católica do Rio Grande do Sul, Porto Alegre, 2016, p. 62-63.

41 A doutrina especializada assegura que ao se falar em sistemas processuais (inquisitivo, acusatório, misto) deve-se essencialmente verificar seu núcleo (gestão da prova) e princípio informador. Se a gestão da prova estiver nas 
percebe-se esta como o primeiro indício de um ânimo persecutório, na medida em que ao juiz cabe julgar e não produzir provas. Não há meio-termo, nem espaço para a conciliação de uma prática forense que vai de encontro com a própria essência do sistema acusatório. ${ }^{42}$

Inúmeras críticas já foram dirigidas aos poderes instrutórios do magistrado. ${ }^{43}$ Não obstante, não é essa a perspectiva adotada pela maioria esmagadora da doutrina processualista brasileira, ${ }^{44}$ à vista do que estabelecem diversos dispositivos de nossa legislação. ${ }^{45}$ Mas, para além dessa questão, o que se quer mesmo acentuar é que conceber poderes instrutórios ao magistrado, retira o foco de análise do que realmente importa para qualquer atividade jurisdicional: a estrita observância ao princípio da imparcialidade, princípio basilar da função jurisdicional. Se o magistrado pode produzir a prova, pode também fundamentar e justificar suas decisões como bem pretender, já que teria a gestão do processo e a gestão da prova em suas mãos. ${ }^{46}$

mãos do julgador teremos um princípio inquisitivo se, por outro lado, estiver nas mãos das partes teremos um princípio dispositivo. Compare em: LOPES JR., Aury. Fundamentos do processo penal: introdução crítica. São Paulo: Saraiva, 2015. p. 158-159.

42 GLOECKNER, Ricardo Jacobsen. Nulidades no processo penal: introdução principiológica à teoria do ato processual irregular. 2 ed. Salvador: JusPodivm, 2015, p. 211.

43 Nesse sentido ver dentre outros: GLOECKNER, Ricardo Jacobsen. Nulidades no processo penal: introdução principiológica à teoria do ato processual irregular. 2 ed. Salvador: JusPodivm, 2015. p. 217-218; LOPES JR., Aury. Direito processual penal. 13. ed. São Paulo: Saraiva, 2016. p. 64-65; PRADO, Geraldo. Sistema acusatório: a conformidade constitucional das leis processuais penais. 4. ed. Rio de Janeiro: Lumen Juris, 2006. p. 140.

44 Por todos: GRINOVER, Ada Pellegrini. A marcha do processo. Rio de Janeiro: Forense Universitária, 2000. p. 79-80.

45 São exemplos os artigos 127, 156, incisos I e II, 196, 209, 242, 310, inciso II, 383 e 385, todos do Código de Processo Penal, que tratam, respectivamente, do sequestro de bens, das diligências na fase pré-processual, do reinterrogatório, das testemunhas do juízo, da busca e apreensão, da conversão da prisão em flagrante em preventiva, da emendatio libelli e do reconhecimento de agravantes na sentença.

46 RITER, Ruiz. Imparcialidade no processo penal: reflexões a partir da teoria da dissonância cognitiva. 2016. 196f. Dissertação (Mestrado em Ciências Criminais) - Faculdade de Direito, Pontifícia Universidade Católica do Rio Grande do Sul, Porto Alegre, 2016, p. 173. 
Sem adentrar no mérito da legalidade e legitimidade da produção probatória pelo magistrado é preocupante a tolerância da sociedade para com o arbítrio estatal, a partir da desvinculação do processo à tutela do acusado (parte hipossuficiente da relação jurídico-processual). É igualmente inquietante a possibilidade de o magistrado ir "em busca da verdade" como justificativa para seu ânimo persecutório. ${ }^{47}$

A atividade jurisdicional deve estar estritamente vinculada à garantia da imparcialidade e sempre que o magistrado indefere sucessivamente os pedidos de produção de provas do acusado nega a produção de outro viés de interpretação sobre o fato, impossibilitando a busca da verdade $;^{48}$ impedindo o cotejo das provas produzidas pela acusação e pela defesa a verificação das possíveis versões dos fatos, necessárias à segurança do juízo, em verdadeira mácula à garantia da imparcialidade. ${ }^{49}$

Negar os pedidos da defesa de produção probatória, em vista de duvidosa fundamentação, ou seja, aquela decorrente do pré-julgamento, fruto da atividade "persecutória", transparece em odioso pré-juízo sobre os fatos, e demonstra o inegável cerceamento do direito de ampla defesa, corolário do devido processo legal, que sustenta toda a evolução processual-penal que nos separa dos julgamentos medievos. No entender de Machado: "O direito da ampla defesa corresponde a uma garantia constitucional conferida ao réu para que este possa se valer, sem

47 GLOECKNER, Ricardo Jacobsen. Nulidades no processo penal: introdução principiológica à teoria do ato processual irregular. 2. ed. Salvador: JusPodivm, 2015. p. 220-221.

${ }_{48}$ Ressalte-se que o termo "verdade" é extremamente complexo e controverso. Ao julgador não incumbe apresentar a verdade real sobre o fato discutido no processo, mas apenas demonstrar, com base no esteio probatório, a sua convicção sobre a ocorrência ou não dos fatos, que acaso não seja segura deverá conduzir necessariamente à absolvição do acusado por força do princípio do in dubio pro reo. Sobre isso, ver: BADARÓ, Gustavo Henrique Righi Ivahy. Ônus da prova no processo penal. São Paulo: Revista dos Tribunais, 2003. p. 61

49 Nesse sentido colaciona Machado: "O art. 5 , LV, da Constituição de 1988 consagra expressamente essa garantia, assegurando, portanto, aos acusados o direito de contrariar a acusação, apresentar livremente quaisquer tipos de teses e argumentos, assim como produzir todas as espécies de provas não proibidas em Lei, visando demonstrar suas pretensões no processo". Sobre isso, ver: MACHADO, Antônio Alberto. Curso de processo penal. 4. ed. São Paulo: Atlas, 2012, p. 64. 
qualquer espécie de embaraço, de todos aqueles mecanismos processuais indispensáveis à salvaguarda de seus direitos. Isto é, a possibilidade de produzir todo tipo de prova, de fazer quaisquer alegações que sejam, de interpor todos os recursos cabíveis, enfim, de demonstrar a pertinência de suas pretensões no processo". ${ }^{50}$ Quando o magistrado colhe a prova, colocando-se à frente na busca pela verdade real, todo indeferimento (a qualquer pleito defensivo) se torna persecutório.

No ponto, há que se considerar suspeito o magistrado que persegue o acusado, impedindo que esse produza os elementos de prova que entenda necessários à comprovação de sua inocência. Os prejuízos decorrentes desse atuar (ilegítimo) persecutório não poderiam ser maiores: legitima-se uma pseudo prática judicial, alheia a uma jurisdição válida e legítima, regida por uma total parcialidade do magistrado. Em outras palavras, o julgador transforma-se em um segundo acusador público (no sentido de outro acusador público - e não de acusador público subsidiário, pois tal postura lhe dá protagonismo), quando deveria manter-se afastado das partes e submetido ao filtro da garantia da imparcialidade. Daí se dizer que "decidir" não é apenas fazer uma escolha entre este ou aquele entendimento, mas, muito mais do que isso, é assumir o compromisso de ter assumido uma posição, de forma fundamentada, consoante ao conjunto probatório, do qual se tornará responsável para sempre. ${ }^{51}$

Contudo, para além da justificativa da escolha de uma interpretação possível sobre os fatos deve o magistrado demonstrar que oportunizou o contraditório da forma mais ampla possível. Nos dizeres de Nucci, deve o magistrado prover a oportunidade "a uma das partes para contestar, impugnar, contrariar ou fornecer uma versão própria acerca de alguma alegação ou atividade contrária ao seu interesse". ${ }^{2}$ Por certo, não há processo bilateral, com igualdade de oportunidades, sem a necessária

50 MACHADO, Antônio Alberto. Curso de processo penal. 4. ed. São Paulo: Atlas, 2012, p. 63-64.

51 RITER, Ruiz. Imparcialidade no processo penal: reflexões a partir da teoria da dissonância cognitiva. 2016. 196f. Dissertação (Mestrado em Ciências Criminais) - Faculdade de Direito, Pontifícia Universidade Católica do Rio Grande do Sul, Porto Alegre, 2016, p. 173-175.

52 NUCCI, Guilherme de Souza. Princípios Constitucionais Penais e Processuais Penais. São Paulo: Revista dos Tribunais, 2010, p. 286. 
obediência ao contraditório, na medida em que este confere a isenção estatal na condução do feito, constituindo limite natural da dialética. Magistrado que justifica uma interpretação, obstando o contraditório, dá ao processo "ares persecutórios". ${ }^{53}$

Carnelutti há tempos enfatizou que a dialética do processo exige a configuração de um magistrado - terceiro, desinteressado e imparcial - que não seja parte na relação jurídica-processual, pois tendendo o acusado a negar a sua culpa e sustentar sua inocência, sem a presença do órgão acusador, restaria ao magistrado o papel de confrontar o acusado no processo, o que acabaria por fulminar sua imparcialidade. ${ }^{54}$

Destarte, tudo aponta, invariavelmente, para a garantia da imparcialidade, conforme relembra Calamandrei: "A imparcialidade, virtude suprema do juiz, é a resultante psicológica de duas parcialidades que se combatem. Não devem os defensores melindrar-se se o juiz - ainda o mais consciencioso - não parece escutar com grande atenção seus discursos em audiência. Está assim porque, antes de pronunciar sua sentença, deve durante longo tempo escutar a discussão tremenda de dois contraditores, que se agitam no fundo da sua consciência". ${ }^{55}$

Diante disso, é possível afirmar que quando o magistrado adentra a função acusadora, negando os pedidos de produção probatória da defesa, acaba por atuar de maneira persecutória, viola-se o princípio acusatório. Tais decisões, ainda que fundamentadas, podem, sim, ser consideradas nulas por atingirem a cláusula da imparcialidade. Magistrado não pode ter "ânimo persecutório". O julgador deve se manter imparcial, afastado das partes, colhendo os elementos de prova que são trazidas de forma espontânea a ele. ${ }^{56}$

53 BADARÓ, Gustavo Henrique Righi Ivahy. Ônus da prova no processo penal. São Paulo: Revista dos Tribunais, 2003. p. 109.

54 CARNELUTTI, Francesco. Derecho procesal civil y penal: principios del proceso penal. Tradução de Santiago Sentis Melendo. Buenos Aires: Ediciones Juridicas Europa-America, 1971, p. 38-39.

55 CALAMANDREI, Piero. Eles, os juízes, vistos por nós, os advogados. São Paulo: Martins Fontes, 2000, p. 49.

56 Nesse sentido ver dentre outros: GLOECKNER, Ricardo Jacobsen. Nulidades no processo penal: introdução principiológica à teoria do ato processual irregular. 2. ed. Salvador: JusPodivm, 2015. p. 217-218; LOPES JR., Aury. Direito processual penal. 13. ed. São Paulo: Saraiva, 2016. p. 64-65; PRADO, Geraldo. 
Certo é que os atores judiciários devem aprender a respeitar as garantias constitucionais, previstas justamente para evitar os excessos e os prejuízos que a subjetividade individual pode trazer ao processo. Nos dizeres de Maya: "devem os julgadores adotar uma postura efetivamente distante (alheia) em relação aos interesses das partes envolvidas na controvérsia judicial, sem se deixar contaminar por eles". ${ }^{57}$

Nenhuma parte deve ser beneficiada em detrimento da outra, mesmo que de forma involuntária. A imparcialidade vincula o sistema acusatório! ${ }^{58} \mathrm{E}$ se optamos por esse modelo de estruturação do processo devemos aprender a adotá-lo por inteiro e não somente as partes que nos convém. Juiz deve julgar, não produzir prova de ofício; juiz deve julgar, não perseguir o acusado por ideologias e demais convicções.

\section{Considerações finais}

O magistrado adquiriu, nas visões atuais do Direito, o papel que a tradição liberal negou. Isso não corresponde a uma única concepção ou escola jurídica, mas envolve o pensamento jurídico contemporâneo como um todo. Ou na forma de reação ao formalismo legal, como no caso de escolas realistas, ou em um processo de análise, como é o caso do positivismo, ou como consciência de sua própria validade da perspectiva do participante e seu esforço para obter respostas legais válidas entre a indeterminação normativa, ou, ainda, no reconhecimento da complexidade resultante da diversidade da vida social e da renúncia ao facilitador metafísico das soluções meramente dualistas, características das teorias jurídicas críticas e dos exames genealogicos e gramaticais. Por trás disso, está a proposta de democratizar a vida prática da lei.

Sistema acusatório: a conformidade constitucional das leis processuais penais. 4. ed. Rio de Janeiro: Lumen Juris, 2006. p. 140.

57 MAYA, André Machado. Imparcialidade e processo penal: da prevenção da competência ao juiz de garantias. 2. ed. São Paulo: Atlas, 2014. p. 99.

58 RITER, Ruiz. Imparcialidade no processo penal: reflexões a partir da teoria da dissonância cognitiva. 2016. 196f. Dissertação (Mestrado em Ciências Criminais) - Faculdade de Direito, Pontifícia Universidade Católica do Rio Grande do Sul, Porto Alegre, 2016, p. 56-57. 
Enfim, se o projeto é de fato pela efetivação de um processo penal constitucional, mostra-se como um excelente ponto de partida a consagração da garantia da imparcialidade como essência da atividade jurisdicional e do devido processo legal, a fim de se ter preservada a cognição do julgador no processo, para que não acabe ruída (como já se vê) a confiança da sociedade no Poder Judiciário. Nessa senda, deve-se salientar, uma vez mais, que a correta compreensão de tal garantia, para além da superada ideia de neutralidade e juiz boca da lei, é a de uma construção jurídica, fruto de uma leitura constitucional do processo penal, que delimita o agir dos magistrados (impondo limites aos prejuízos que sua subjetividade pode causar nos julgamentos), que somente atuarão de forma imparcial se conduzirem o processo como terceiros desinteressados em relação às partes, comprometendo-se, contudo, em apreciar na totalidade ambas as versões apresentadas sobre os fatos postos em exame, proporcionando sempre igualdade de tratamento e oportunidades aos envolvidos (princípio do contraditório).

Nessa seara, e em consonância com o objetivo do presente artigo, que foi a verificação da existência de um ânimo persecutório do magistrado, que sucessivamente adota uma postura decisionista contrária ao direito à prova defensiva, foi possível concluir pela existência da quebra do dever de imparcialidade do julgador. Isto porque, tem-se que o processo penal acusatório (cujo núcleo é a gestão da prova, e o princípio informador o dispositivo) deve constituir-se por sujeitos parciais (acusador público e acusado) e um sujeito imparcial (juiz), restando ao julgador tão somente a condição de terceiro desinteressado em relação às partes, alheio aos interesses processuais, sob pena de se ter fulminada sua imparcialidade, e consequentemente, ver-se invalidada a jurisdição que lhe compete.

Por conseguinte, o magistrado, para além da justificativa da escolha de uma interpretação aceitável sobre os fatos deve demonstrar que oportunizou o contraditório da forma mais ampla possível. Negar todos os pedidos da defesa, em vista de controversa fundamentação, transparece em odioso prejulgamento, e demonstra o inegável cerceamento do direito de ampla defesa. Assim, há que se considerar suspeito o magistrado que persegue o acusado, impedindo que esse produza os elementos de prova necessários à sua absolvição. Dito de outra forma, o julgador acaba por transformar-se em um segundo acusador público, quando deveria manter-se afastado das partes e submetido ao filtro da garantia da imparcialidade. 
A questão é simples: a busca da verdade não pode servir como recurso discursivo, que permita aos magistrados desprezar e desmerecer a função do acusado e do acusador público no processo penal, fazendo valer sua figura de protagonista no processo. Juiz somente julga. A narrativa acusatória deverá ficar a cargo do acusador público, na medida em que ao tomar postura persecutória o magistrado acaba por violar o contraditório e a ampla defesa, já que inviabiliza a Defesa técnica e a autodefesa de contraditar a interpretação das provas que permitiria eventual condenação.

Magistrado que persegue o acusado viola a imparcialidade e a própria concepção de jurisdição. Isto porque a imparcialidade está umbilicalmente relacionada com a ideia de jurisdição. O monopólio do estado-juiz sobre a jurisdição e a vedação à autotutela impõe que o magistrado atue de forma absolutamente imparcial. Não há como conciliar o ânimo persecutório do magistrado com a garantia da imparcialidade e o sistema acusatório.

\section{REFERÊNCIAS}

ARAMBURO RESTREPO, José Luís. El papel del juez: una aproximación teórica. Pensamiento Jurídico, Bogotá, ano 16, n. 27, p. 85-106, jan./abr. 2010.

ARAÚJO, Francisco Fernandes de. A parcialidade dos juízes. Campinas: Edicamp, 2002.

BADARÓ, Gustavo Henrique Righi Ivahly. Direito a um julgamento por juiz imparcial: como assegurar a imparcialidade objetiva do juiz nos sistemas em que não há a função do juiz de garantias. In: BONATO, Gilson (Org.). Processo Penal, Constituição e Críticas - Estudos em homenagem ao Prof. Dr. Jacinto Nelson de Miranda Coutinho. Rio de Janeiro: Lumen Juris, 2011. p. 343-360.

BADARÓ, Gustavo Henrique Righi Ivahy. Direito processual penal. Tomo I. Rio de Janeiro: Elsevier, 2008.

BADARÓ, Gustavo Henrique Righi Ivahy. Ônus da prova no processo penal. São Paulo: Revista dos Tribunais, 2003.

BATISTA, Bárbara Gomes Lupetti. Reflexões sobre o dever de fundamentação das decisões judiciais e a imparcialidade judicial: "o que falar quer dizer" e o que dizer não quer falar? Amazon's Research and Environmental Law, Ariquemes, ano 3, n. 3, p. 107-130, set. 2015. https://doi.org/10.14690/2317-8442.2015v33169 
CABRAL, Antônio. Imparcialidade e impartialidade. Por uma teoria sobre repartição e incompatibilidade de funções nos processos civil e penal. Revista de Processo, São Paulo, ano 32, n. 149, p. 339-364, jul. 2007.

CALAMANDREI, Piero. Eles, os juízes, vistos por nós, os advogados. São Paulo: Martins Fontes, 2000.

CARNELUTTI, Francesco. Derecho procesal civil y penal: principios del proceso penal. Tradução de Santiago Sentis Melendo. Buenos Aires: Ediciones Juridicas Europa-America, 1971.

CARVALHO, Saulo de. O papel dos atores no sistema penal na era do punitivismo. O exemplo privilegiado da aplicação da pena. Rio de Janeiro: Lumen Juris, 2010. CORDÓN MORENO, Faustino. Las garantias constitucionales del proceso penal. 2. ed. Navarra: Arazandi, SA, 2002.

COUTINHO, Jacinto Nelson de Miranda. Introdução aos princípios gerais do Direito Processual Penal Brasileiro. Revista de Estudos Criminais, Porto Alegre, ano 1, n. 1, p. 26-51, jul. 2001.

EYMERICH, Nicolau. Directorium Inquisitorum: Manual dos Inquisidores: Escrito por Nicolau Eymerich em 1376, revisto e ampliado por Francisco de La Peña em 1578. Rio de Janeiro: Rosa dos Ventos, Brasília: Fundação Universidade de Brasília, 1993.

FAZZALARI, Elio. Instituições de Direito Processual. Tradução de Eliane Nassif. 8. ed. Campinas: Imprenta, 2006.

GIACOMOLLI, Nereu José. O devido processo penal. Abordagem conforme a Constituição Federal e o Pacto de São José da Costa Rica. Cases da Corte Interamericana, do Tribunal Europeu e do STF. Porto Alegre: Atlas. 2. ed., 2015.

GIACOMOLLI, Nereu José; DUARTE, Liza Bastos. O mito da neutralidade na motivação das decisões judiciais: aspectos epistemológicos. Revista da Ajuris, Porto Alegre, ano 33, n. 102, p. 288-307, jun. 2006.

GLOECKNER, Ricardo Jacobsen. Nulidades no processo penal: introdução principiológica à teoria do ato processual irregular. 2. ed. Salvador: JusPodivm, 2015.

GOLDSCHMIDT, Werner. La imparcialidad como principio básico del proceso: la partialidad y la parcialidade. Madrid: Gráfica Clemares, 1950.

GRINOVER, Ada Pellegrini. A iniciativa instrutória do Juiz no processo penal acusatório. Revista Forense, Rio de Janeiro, ano 95, n. 347, p. 72-79, jul./set. 1999. GRINOVER, Ada Pellegrini. A marcha do processo. Rio de Janeiro: Forense Universitária, 2000. 
GRINOVER, Ada Pellegrini; FERNANDES, Antônio Scarance; GOMES FILHO, Antônio Magalhães. As Nulidades do Processo Penal. 4. ed. São Paulo: Malheiros, 1995. KENNEDY, Duncan. Libertad y restricción en la decisión judicial. Bogotá: Universidad de Los Andes, 1998.

LARENZ, Karl. Metodología de la Ciencia del Derecho. Barcelona: Ariel, 1994.

LEONE, Giovanni. Come si svolge un processo penale. Torino: ERI, 1967.

LOPES JR., Aury. Direito processual penal. 10. ed. São Paulo: Saraiva, 2013.

LOPES JR., Aury. (Re)pensando os sistemas processuais penais em democracia: a estafa do tradicional problema inquisitório $\mathrm{x}$ acusatório. Boletim Informativo IBRASPP, São Paulo, ano 03, n. 05, p. 17-18, fev. 2013.

LOPES JR., Aury. Fundamentos do processo penal: introdução crítica. São Paulo: Saraiva, 2015.

MACHADO, Antônio Alberto. Curso de processo penal. 4. ed. São Paulo: Atlas, 2012.

MARINHO MARQUES, Leonardo Augusto. Inquisitório versus acusatório: não vamos superar a dualidade sem demarcá-la. Boletim Informativo IBRASPP, São Paulo, ano 03, n. 04, p. 9-10, jan. 2013.

MAYA, André Machado. Imparcialidade e processo penal: da prevenção da competência ao juiz de garantias. 2. ed. São Paulo: Atlas, 2014.

MONTESQUIEU, Charles de Secondat, Baron de. O espírito das leis. Tradução de Cristina Murachco. São Paulo: Martins Fontes, 1996.

MOREIRA, José Carlos Barbosa. A motivação das decisões judiciais como garantia inerente ao Estado de Direito. In: Temas de Direito Processual. São Paulo: Saraiva, 1988.

NALINI, José Renator. Humildade do juiz. Disponível em: <http://portal.tjro. jus.br/documents/18/24335/A+HUMILDADE+DO+JUIZ.pdf>. Acesso em: 06 de fev. 2018.

NUCCI, Guilherme de Souza. Princípios Constitucionais Penais e Processuais Penais. São Paulo: Revista dos Tribunais, 2010.

POZZEBON, Fabrício Dreyer de Ávila. A imparcialidade do juiz criminal enquanto ausência de causas de impedimento ou de suspeição. Direito e Justiça, Porto Alegre, ano 39, n.1, p. 116-220, jan./jun. 2013.

POZZEBON, Fabrício Dreyer de Ávila. A imparcialidade do juiz no processo penal brasileiro. Revista da Ajuris, Porto Alegre, ano 34, n. 108, p-116-120, dez. 2007.

PRADO, Geraldo. Sistema acusatório: a conformidade constitucional das leis processuais penais. 4. ed. Rio de Janeiro: Lumen Juris, 2006. 
RITER, Ruiz. Imparcialidade no processo penal: reflexões a partir da teoria da dissonância cognitiva. 2016. 196f. Dissertação (Mestrado em Ciências Criminais) - Faculdade de Direito, Pontifícia Universidade Católica do Rio Grande do Sul, Porto Alegre, 2016.

URARI, Marcelo Fernandez Cardillo de Morais. Modos de obtenção do convencimento do julgador: análise dos sistemas processuais penais. 2009. 173f. Dissertação (Mestrado em Ciências Criminais) - Faculdade de Direito, Pontifícia Universidade Católica do Rio Grande do Sul, Porto Alegre, 2009.

ZAFFARONI, Eugênio Raul. Poder Judiciário: Crises acertos e desacertos. Tradução: Juarez Tavares. São Paulo: Revista dos Tribunais, 1995.

\section{Informações adicionais e declarações dos autores (integridade científica)}

Declaração de conflito de interesses (conflict of interest declaration): os autores confirmam que não há conflitos de interesse na realização das pesquisas expostas e na redação deste artigo.

Declaração de autoria e especificação das contribuições (declaration of authorship): todas e somente as pessoas que atendem os requisitos de autoria deste artigo estão listadas como autores; todos os coautores se responsabilizam integralmente por este trabalho em sua totalidade.

- Fábio Agne Fayet: levantamento bibliográfico, revisão bibliográfica, revisão crítica com contribuições substanciais, aprovação da versão final.

- Roberta Eggert Poll: projeto e esboço inicial, levantamento bibliográfico, revisão bibliográfica, redação, revisão crítica com contribuições substanciais, aprovação da versão final.

Declaração de ineditismo e originalidade (declaration of originality): os autores asseguram que o texto aqui publicado não foi divulgado anteriormente em outro meio e que futura republicação somente se realizará com a indicação expressa da referência desta publicação original; também atestam que não há plágio de terceiros ou autoplágio. 
Dados do processo editorial

(http://www.ibraspp.com.br/revista/index.php/RBDPP/about/editorialPolicies)

- Recebido em: 07/04/2018

- Controle preliminar e verificação de plágio: 08/04/2018

- Avaliação 1: 12/04/2018

- Avaliação 2: 22/04/2018

- Avaliação 3: 23/04/2018

- Decisão editorial preliminar: 02/05/2018

Equipe editorial envolvida

- Editor-chefe: 1 (VGV)

- Editora-associada: 1 (LBW)

- Editor-assistente: 1 (TACJ)

- Revisores: 3

- Retorno rodada de correções 1: 10/10/2018

- Decisão editorial final: 20/05/2018

\section{COMO CITAR ESTE ARTIGO:}

FAYET, Fábio Agne; POLL, Roberta Eggert. Ânimo persecutório do magistrado: a quebra do dever de imparcialidade e sucessivas decisões contrárias ao direito à prova defensiva. Revista Brasileira de Direito Processual Penal, Porto Alegre, v. 3, n. 2, p. 645-667, mai./ago. 2018. https://doi.org/10.22197/rbdpp.v4i2.143

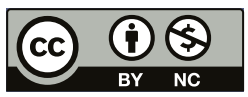

Esta obra está licenciada com uma Licença Creative Commons Atribuição-NãoComercial 4.0 Internacional. 